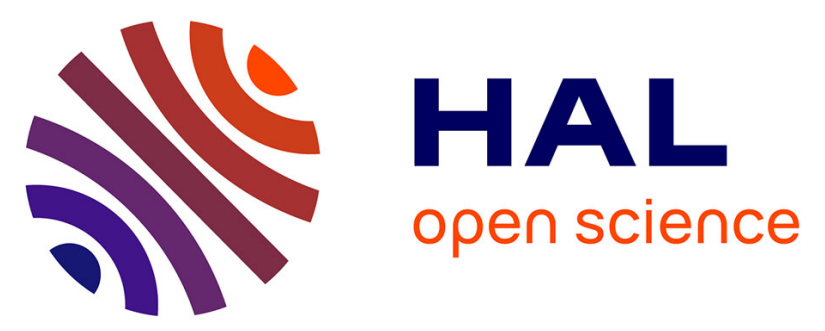

\title{
Blue-Green Algae in a "Greenhouse Century"? New Insights from Field Data on Climate Change Impacts on Cyanobacteria Abundance
}

\author{
Orlane Anneville, Isabelle Domaizon, Onur Kerimoglu, Frédéric Rimet, \\ Stéphan Jacquet
}

\section{To cite this version:}

Orlane Anneville, Isabelle Domaizon, Onur Kerimoglu, Frédéric Rimet, Stéphan Jacquet. Blue-Green Algae in a "Greenhouse Century"? New Insights from Field Data on Climate Change Impacts on Cyanobacteria Abundance. Ecosystems, 2015, 18 (3), pp.441-458. 10.1007/s10021-014-9837-6 . hal02916371

\section{HAL Id: hal-02916371 \\ https://hal.inrae.fr/hal-02916371}

Submitted on 17 Aug 2020

HAL is a multi-disciplinary open access archive for the deposit and dissemination of scientific research documents, whether they are published or not. The documents may come from teaching and research institutions in France or abroad, or from public or private research centers.
L'archive ouverte pluridisciplinaire HAL, est destinée au dépôt et à la diffusion de documents scientifiques de niveau recherche, publiés ou non, émanant des établissements d'enseignement et de recherche français ou étrangers, des laboratoires publics ou privés. 


\title{
Blue-Green Algae in a "Greenhouse Century"? New Insights from Field Data on Climate Change Impacts on Cyanobacteria Abundance
}

\author{
Orlane Anneville, ${ }^{1,2 *}$ Isabelle Domaizon, ${ }^{1,2}$ Onur Kerimoglu, ${ }^{1,2,3}$ \\ Frédéric Rimet, ${ }^{1,2}$ and Stéphan Jacquet ${ }^{1,2}$ \\ ${ }^{1}$ CARRTEL, INRA, 75 Avenue de Corzent, 74203 Thonon-les-Bains, France; ${ }^{2}$ CARRTEL, Université de Savoie, 73370 Le Bourget du \\ Lac, France; ${ }^{3}$ Institute of Coastal Research, Helmholtz-Zentrum, Geesthacht, Germany
}

\begin{abstract}
Climate warming is likely to impact phytoplankton communities by providing a habitat in which cyanobacteria have competitive advantage over other phytoplankton taxa. We used extreme hot weather periods to investigate the potential impact of climate change on cyanobacteria abundance in three large and deep peri-alpine lakes, Lakes Geneva, Annecy, and Bourget. Between 2000 and 2011, there were four extreme warm weather periods: spring and summer 2003, autumn 2006 and winter 2007. We found that the consequences of extreme air temperatures on cyanobacteria abundance and phytoplankton composition depend on the time of year in which the extreme temperatures occur. In all three lakes studied, a warm summer did not clearly promote cyanobacteria blooms, whereas a warm autumn promoted cyanobacteria growth in the mesotrophic Lakes Geneva and Bourget, but not in the oligotrophic Lake Annecy. A warm
\end{abstract}

winter was associated with high cyanobacteria abundance and a high contribution of cyanobacteria to total phytoplankton biomass. Our results reinforce the idea that lakes have an ecological memory by showing that a warm winter can influence subsequent seasonal succession in the cyanobacteria community. In both mesotrophic lakes studied, cyanobacteria abundance was strongly influenced by phosphorus concentrations and winter air temperatures. We conclude that although extreme hot weather periods can be used to analyze various aspects of the impacts of climate change, they are of limited value in forecasting the structure of phytoplankton communities in a warmer future.

Key words: climatic forcing; extreme events; temperature; warming; phytoplankton; lakes; heat wave; water quality; eutrophication.
Received 26 May 2014; accepted 14 November 2014; published online 15 January 2015

Authors contribution OA prepared and analyzed the data, proceeded to article's review and wrote the manuscript. ID prepared the data, proceeded to article's review and wrote the manuscript. OK prepared the data, proceeded to article's review and wrote the manuscript. FR contributed data and proceeded to article's review. SJ prepared the data, proceeded to article's review and wrote the manuscript.

*Corresponding author; e-mail: orlane.anneville@thonon.inra.fr

\section{INTRODUCTION}

Global average air temperature increased by approximately $0.6^{\circ} \mathrm{C}$ in the twentieth century (IPCC 2001; Cubasch and others 2013) and global circulation models predict that it may increase by 1.7 to $4.9^{\circ} \mathrm{C}$ over the next century (Wigley and Raper 2001). Cyanobacteria, formerly referred to as 
blue-green algae, are autotrophic oxygenic prokaryotes. They comprise a large variety of species and possess a number of morpho-functional traits that could make some of them well adapted to the environmental conditions associated with global warming, such as high nutrient loading, rising temperatures, enhanced stratification, increased residence time, and salinization (Pearl and Huisman 2008; Carey and others 2012; Ekvall and others 2013). Consequently, speculations that climate change may increase cyanobacteria abundance has given rise to increasing concerns over lake use and management because cyanobacteria are known for their ability to form blooms (Reynolds 2006) and produce toxins (Sivonen and Jones 1999). In the past decade, the impact of climate change on cyanobacteria populations has become a major concern in environmental sciences, leading to a steadily increasing number of studies on the topic.

It has been proposed that the impact of warming on lakes is modulated by the amount of nutrient resources (Winder and Sommer 2012), and hence trophic status of the lake and/or climate-related changes in nutrient loading (Elliott 2012; Arheimer and others 2005).

Modelling studies generally predict increased cyanobacteria biomass and/or dominance with increasing water temperature and climate-induced changes in the thermal regime (Jöhnk and others 2008; Trolle and others 2011; Elliott 2012). Although several time series analyses of plankton data have shown a tight link between climatic forcing and variability in phenology (Scheffer and others 2001; Edwards and Richardson 2004; Winder and Schindler 2004; Adrian and others 2009), only a few studies based on field observations of phytoplankton communities have clearly shown an increase in cyanobacteria abundance in response to climate warming. Comparative and long-term studies have shown that warmer conditions are indeed associated with higher cyanobacteria abundance. For example, the percentage of cyanobacteria in the phytoplankton community is higher in warm than in cold shallow lakes (Kosten and others 2012), warmer winters favor growth and inoculum production in certain species (Anneville and others 2004; Weyhenmeyer 2001; Adrian and others 1995; Jacquet and others $2014 \mathrm{~b}$ ). The above-mentioned field and modelling studies, as well as the experimental work (De Senerpont Domis and others 2007), provide some evidence that climate warming likely favors cyanobacterial forms. There is also the general finding that cyanobacteria grow better at higher temperatures and possess morphological, physiological, and behavioral traits that confer advantages in strongly stratified environments (Winder and Sommer 2012). Distinct competitive advantages of cyanobacteria over other taxa would principally arise from the ability of cyanobacteria to efficiently capture and utilize spatially segregated resources (light and nutrients). Cyanobacteria should gain advantage from their capacities to (1) regulate their position through buoyancy, (2) capture light at low intensities over a wide range of wavelengths thanks to the accessory pigmentation and the structural organization of their light-harvesting antenna, (3) access organic phosphorus thanks to phosphatases, and (4) to store luxury phosphorus (Carey and others 2012).

In support of this hypothesis, recent comparative studies show that water temperature is indeed a predictor of cyanobacteria abundance. However, at the same time, these studies emphasize the role played by nutrients, trophic status (Beaulieu and others 2013; Rigosi and others 2014) or even mixing regime of the lake (Taranu and others 2012), and demonstrate that the response of cyanobacteria to climate change relies upon complex interactions between nutrient availability and climate-related variables (Kosten and others 2012). Some empirical evidence from long-term data point to the impact of confounding factors, such as phosphorus concentrations, that are stronger than, or act in synergy with, meteorological fluctuations and atmospheric modes of variability, to explain observed changes in phytoplankton communities (Jeppesen and others 2003; Anneville and others 2002, 2004; Shatwell and others 2008; Stich and Brinker 2010; Salmaso and Cerasino 2012).

This is largely due to a lack of homogeneous phytoplankton time-series that cover a time-period long enough to include strong hydrological modifications which might induce significant changes in cyanobacteria abundances. Indeed, very few phytoplankton time-series extend back to before the 1960s, and phytoplankton time-series usually cover a time-period that is long enough to capture important changes in key environmental parameters, like phosphorus concentrations (Jeppesen and others 2005), whose effects are often stronger or combine with those induced by climate change (for example, Stich and Brinker 2010; Pomati and others 2012).

Paleolimnology has helped solve this problem by broadening the time-period studied (for example, Alric and others 2013; Berthon and others 2013). Furthermore, cyanobacterial biomarkers like pigments and DNA are starting to be included in 
paleolimnological approaches, revealing the relative importance of nutrients and warming on cyanobacteria dynamics (Domaizon and others 2013; Savichtcheva and others 2014).

An alternative way of studying the impact of climate warming on cyanobacteria abundance is to focus on extreme meteorological events (Gallina and others 2011; Huber and others 2012). Most of the global warming debate focuses on changes in global average temperature anomalies. However, climate change is characterized by important interannual variability and the occurrence of extreme conditions at certain periods of the year. As statistical methods summarize patterns within data, such extremes are usually lost in temporal averages, and the impact of climate variability has long been neglected. Only recently have researchers started analyzing the impact of extreme weather events (Jentsch and others 2007). In fact, a number of studies have shown that extreme weather events strongly impact hydrodynamics and plankton communities (Jankowski and others 2006; Straile and others 2010; Anneville and others 2010; Gallina and others 2011). Research also suggests that the impact of climate extremes is different from the impacts of mean climate change such as the increase in mean water temperature for instance (Mearns and others 1997; Straile and others 2010).

It is crucial to assess the impact of warm extreme events because such events are expected to occur more frequently in the future and are characteristic of global warming (Beniston 2007). The present study addresses the impact of such events on cyanobacteria abundance in deep peri-alpine lakes. Our objective is to test, using historical data, if cyanobacteria perform better and bloom during exceptional hot weather periods (EHWPs). To answer these questions, we analyzed long-term phytoplankton data from Lakes Geneva, Annecy, and Bourget. These three lakes differ in trophic status and morphology (Jacquet and others 2014a). We examined data for a ten-year period to determine if: (i) the occurrence of an EHWP significantly impacts the seasonal dynamics of cyanobacteria, (ii) an EHWP increases the abundance of cyanobacteria and induces a change in the composition of the phytoplankton community, and (iii) at the interannual scale, cyanobacteria abundance is driven by air temperature.

What is today considered an extreme meteorological condition may become the norm in a future warmer climate (Beniston 2007). It has therefore been suggested that an EHWP may be a useful tool for predicting the impact of climate warming (Jankowski and others 2006; Huber and others
2010; Gallina and others 2011). However, the general applicability of an EHWP is unclear; for example, we know that it cannot be used for all variables and it is inappropriate for predicting changes in water temperature (Straile and others 2010). Drawing on our results for Lakes Geneva, Annecy, and Bourget, we discuss two main questions regarding the use of EHWPs: can they serve to analyze the impact of climate change and, can they be used to empirically test models and conceptual predictions about the impact of climate warming on cyanobacteria.

\section{Materials And Methods}

\section{Lakes}

Lakes Geneva, Annecy, and Bourget are located in the western part of the Alps (Figure 1). They are large, never freeze over, and are thermally stratified during much of the year (Table 1). These three lakes differ in mixing regime and trophic status. Although Lake Geneva does not undergo complete mixing every year, Lakes Annecy and Bourget regularly undergo winter mixing over the entire water column. Finally, in contrast to Lake Annecy, which has not suffered from large increases in phosphorus concentrations over the past 40 years, Lakes Geneva and Bourget have been eutrophic for several years (Jacquet and others 2014a). In all three lakes, measures to reduce phosphorus loading in the watersheds were implemented in the 1970s, leading to a decrease in phosphorus concentrations starting in the early 1980s. In Lake Geneva, annual average total phosphorus concentration dropped from 89.5 to $21.6 \mu \mathrm{g} \mathrm{P}^{-1}$ (Lazzarotto and others 2013), in Lake Bourget winter average total phosphorus concentration dropped from 150 to $14 \mu \mathrm{g} \mathrm{P}^{-1}$ between 1980 and 2012 (Jacquet and others 2013). In Lake Annecy, the annual concentrations of total phosphorus remained rather stable over the last 30 years with an average of $6 \pm 1.9 \mu \mathrm{g} \mathrm{P}^{-1}$ (Domaizon and others 2014). Lakes Annecy, Bourget, and Geneva are now respectively oligotrophic, oligo-mesotrophic, and mesotrophic (Jacquet and others 2014a).

\section{Sampling}

Lakes Annecy, Bourget, and Geneva are currently being monitored as part of a long-term water quality and biological monitoring program. As new sampling protocols for measuring physical and chemical parameters, as well as plankton abundance and composition were implemented in 2000 (Jacquet and others 2014a), we use only data 


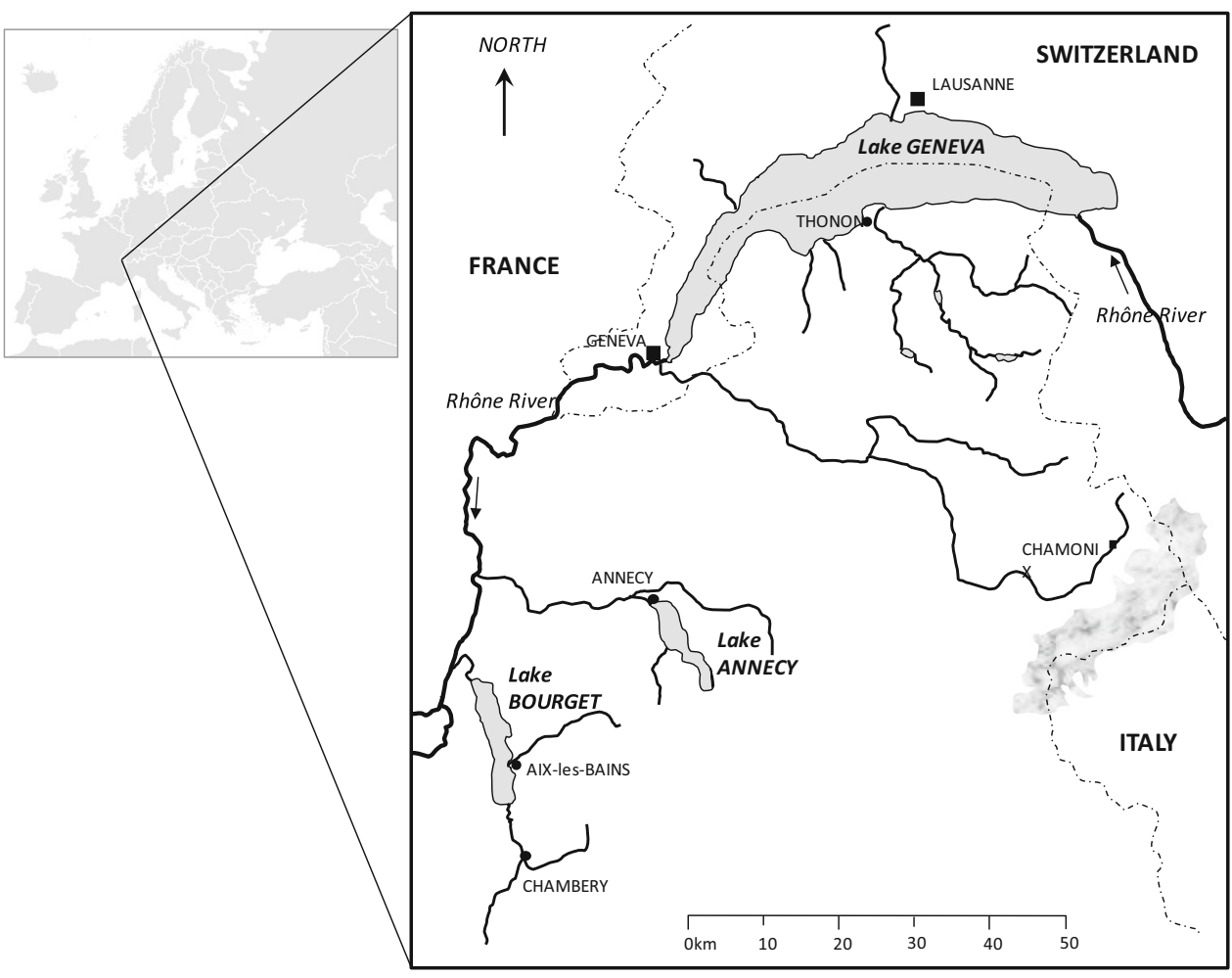

Figure 1. A map showing the location of the studied lakes in the western range of the Alps (from north to south: L. Geneva, Annecy and Bourget).

Table 1. Geographical Location and Morphological Characteristics of the Lakes Geneva, Bourget, and Annecy (from Jacquet and others 2014a)

\begin{tabular}{|c|c|c|c|c|c|c|c|}
\hline Lake & Latitude & Longitude & $\begin{array}{l}\text { Elevation } \\
(\mathrm{m})\end{array}$ & $\begin{array}{l}\text { Mean depth } \\
\text { (m) }\end{array}$ & $\begin{array}{l}\text { Max. depth } \\
\text { (m) }\end{array}$ & $\begin{array}{l}\text { Surface } \\
\text { area }\left(\mathrm{km}^{2}\right)\end{array}$ & $\begin{array}{l}\text { Watershed } \\
\text { area }\left(\mathrm{km}^{2}\right)\end{array}$ \\
\hline Geneva & $46^{\circ} 27^{\prime} \mathrm{N}$ & $6^{\circ} 32^{\prime} \mathrm{E}$ & 372 & 153 & 310 & 580 & 7,419 \\
\hline Bourget & $45^{\circ} 76^{\prime} \mathrm{N}$ & $5^{\circ} 86^{\prime} \mathrm{E}$ & 231 & 80 & 145 & 44 & 588 \\
\hline Annecy & $45^{\circ} 51^{\prime} \mathrm{N}$ & $6^{\circ} 10^{\prime} \mathrm{E}$ & 447 & 41 & 65 & 27 & 278 \\
\hline
\end{tabular}

collected following this, from 2000 to 2011. This limits any bias due to changes in sampling protocol.

The lakes were sampled at a single station located at the deepest point in the lake basin. Sampling was carried out once a month in winter and twice a month in spring, summer, and autumn. Water temperature was measured using a multiparameter probe. Water for nutrient concentration measurements was sampled at a series of discrete depths between the surface and bottom of the lake. The analytical methods used are detailed in a CIPEL annual report (Monod and others 1984) and on the website dedicated to the observatory of alpine lakes ("http://www6.inra.fr/soere-ola").

The water samples for identification and estimation of phytoplankton abundance and composition were collected using a custom-made integrating bell sampler (Pelletier and Orand 1978). The samples were taken in the upper 18 and $20 \mathrm{~m}$ in Lakes Geneva and Annecy, respectively. In Lake Bourget the depth integration was 2.5 times the transparency found using the white disc until 2005 and 0-20 m subsequently (Jacquet and others 2014a). Phytoplankton identification and cell counts were done in sedimentation chambers under an inverted microscope using the Utermöhl technique (1958), which has been standardized (Afnor 2006). Species biovolumes were derived from cell numbers and mean cell volumes using geometrical models. We then estimated total biomass by adding the biovolumes for each species, assuming a fresh weight of $1 \mathrm{~g} \mathrm{~cm}^{-3}$. No data for phytoplankton abundance were available in 2003 for Lake Bourget, except for the cyanobacterium Planktothrix rubescens at discrete depths $(2,6,10,15$, and $20 \mathrm{~m})$.

\section{Identification of EHWPs}

We identified years with extreme meteorological conditions using air temperature measured at the 
INRA meteorological station, which is located at the western fringe of the Alps, on the south coast of Lake Geneva $\left(46^{\circ} 22^{\prime} \mathrm{N}-6^{\circ} 27^{\prime} 17^{\prime \prime} \mathrm{E}\right)$. Air temperature seasonal means were calculated for each year: winter (January, February, March), spring (April, May, June), summer (July, August, September), and autumn (October, November, December). An EHWP was identified for each season according to the method described in Gallina and others (2011). We calculated 99th percentiles for seasonal mean air temperature for the period 2000-2011 and for each season. An EHWP was then identified as a period of time whose seasonal mean was higher than the 99th percentile recorded for the study period (2000-2011).

\section{Analyses}

We used principal component analysis (PCA) to examine the impact of EHWPs on the annual dynamics of cyanobacteria. The PCA was run on the abundance of phytoplankton groups (PPG) as identified based on Bourelly's classification (Bourrelly 1972, 1981, 1985) which relies on morphology and pigment content. We have identified nine PPG in the studied lakes: Zygophyceae, Chlorophyceae, Diatomophyceae, Xanthophyceae, Chrysophyceae, Euglenophyceae, Cryptophyceae, Dinophyceae, and Cyanobacteria. Values for PPG biomass were $\mathrm{ln}$-transformed and centred. We ran a PCA for each year and each lake to identify annual variability in cyanobacteria compared to other phytoplankton taxa. If an EHWP favors cyanobacteria, there should be higher variability in cyanobacteria abundance during a year with an EHWP versus other years. In terms of the PCA, if an EHWP favors a cyanobacterial bloom, the relative contribution of cyanobacteria to the formation of the PCA axis should be higher during years with an EHWP.

Inter-annual changes in phytoplankton composition were analyzed using between-groups PCA. The goal of the method is to describe betweengroup variability (Dolédec and Chessel 1989). The method consists of running a PCA on the groupweighted mean values of the variables. The weight of each group is computed during the analysis and is proportional to the number of samples in the group. In our study, the years constituted the groups, and PPG biomass the variables. We performed the analysis for each season and each lake separately. Taxa biomass was ln-transformed and centered before being entered in the analyses. We chose to use between-group PCA because this method effectively removes any background noise related to phytoplankton variability over the season and focuses, instead, on inter-annual changes.

\section{RESUltS \\ Identification of Seasonal EHWPs}

Although air temperature showed pronounced seasonal changes, no long-term increase in annual mean air temperature could be observed between 2000 and 2011 (Figure 2A). Within this time period there was, however, strong inter-annual variability (Figure 2B). The identified EHWPs were: winter 2007, spring and summer 2003, and autumn 2006. Air temperature anomalies were rather similar during these EHWPs: $+1.9,+1.5,+1.9$ and $+1.8^{\circ} \mathrm{C}$ in winter, spring, summer, and autumn, respectively (Figure 2B).

\section{Cyanobacteria Community Structure}

In total, $97 \%$ of the cyanobacterial biomass was made up of three species in Lake Bourget, four species in Lake Annecy, and seven species in Lake Geneva (Table 2). In both Lakes Geneva and Bourget, the three dominant genera were Planktothrix, Aphanizomenon, and Aphanocapsa. The cyanobacteria community was strongly dominated by Planktothrix and, more specifically P. rubescens. This species also dominated in Lakes Bourget and Geneva during the four identified EHWPs. In Lake Annecy, the composition was different: Aphanocapsa along with Chroococcus dominated the community, that is, they were more abundant than the other species during the EHWPs. It is noteworthy that the picocyanobacteria were an abundant group in all three lakes (Personnic and others 2009; Jacquet and others 2013). However, this group, merely represented by small-sized phycoerythrinrich Synechococcus spp. (Personnic and others 2009), were not considered in this study.

\section{Impact of EHWPs on Annual Variability in Cyanobacteria Abundance}

In Lake Annecy, cyanobacteria tended to show an annual dynamic characterized by higher abundances at the end of the year. However, no clear recurrent and characteristic annual pattern could be identified because differences between months were not significant (Figure 3). In Lake Geneva and Bourget, where cyanobacteria were more abundant, their biomass showed a pronounced annual pattern with significant differences between some months (Figure 3). In these lakes, cyanobacteria demonstrate clear seasonal patterns char- 


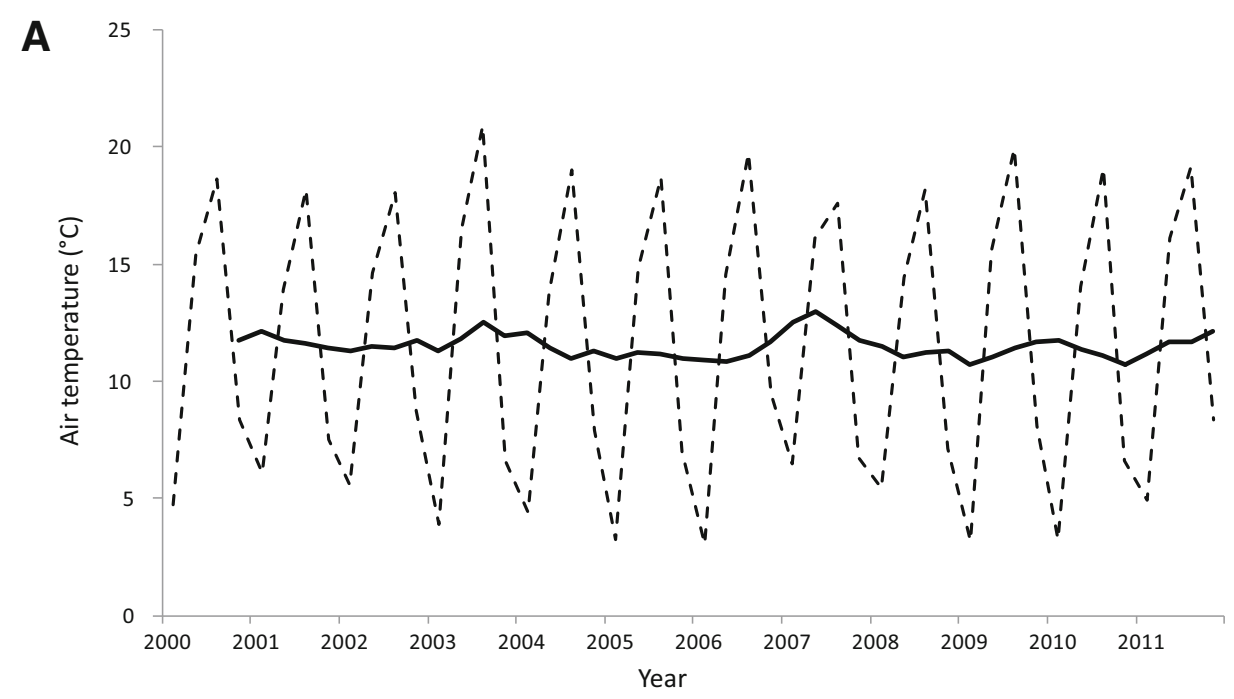

Figure 2. A Long-term changes in seasonal mean air temperature (dotted line) and 4-year moving average air temperature (solid line). B Long-term changes in seasonal air temperature anomalies measured at the INRA meteorological station from 2000 to 2011 . The horizontal line indicates the 99th percentile for seasonal air temperature.

B
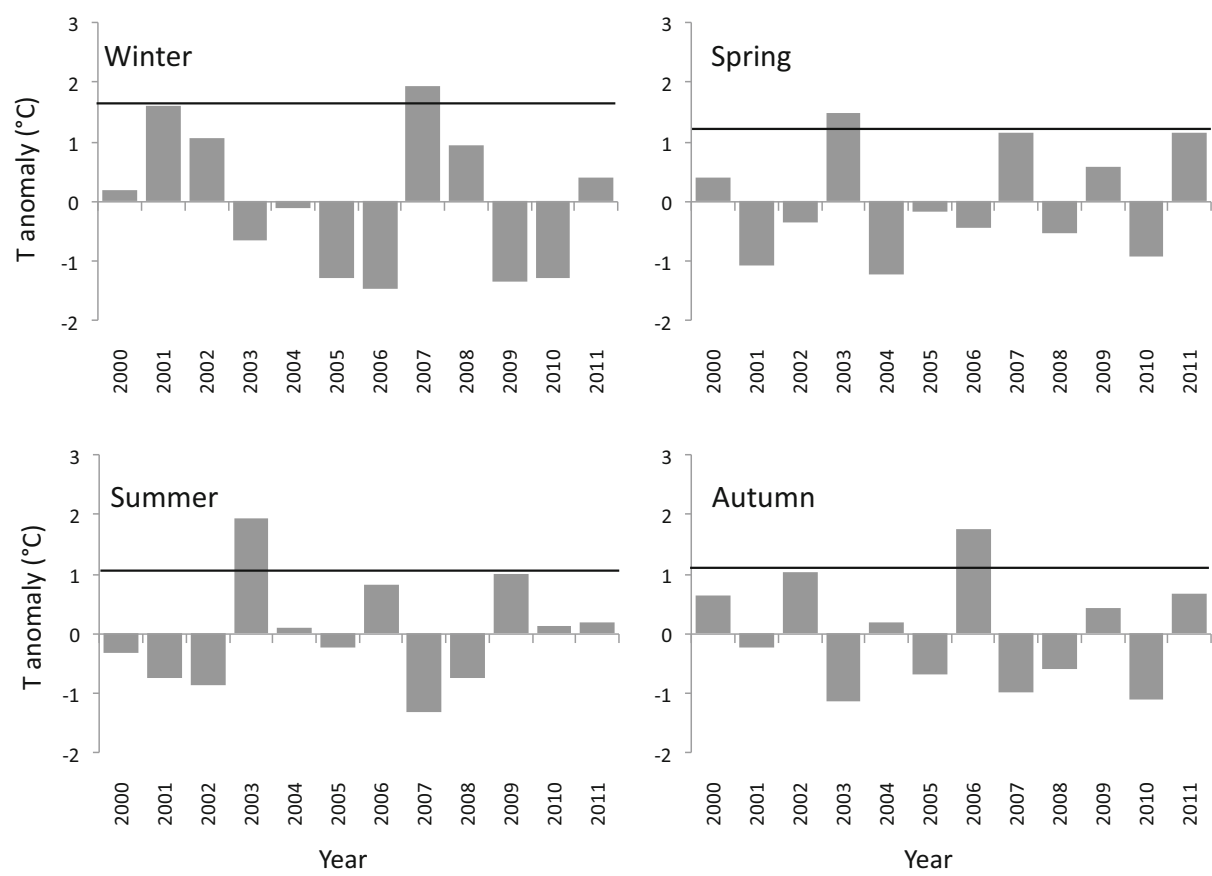

acterized by low biomass in winter and maximum biomass in summer and autumn.

The relative contributions of cyanobacteria to the formation of the first, second, and third PCA axes are proportional to the size of the circles shown in Figure 4A. The relative contribution of cyanobacteria to the formation of the first three axes was not exceptionally high during years of an EHWP. Rather, the contributions were generally low, except in 2006 (Figure 4A). In 2003 and 2007, low contributions indicated low annual variability in cyanobacteria abundance and, thus, no occasional blooms during the EHWP associated with these years. Indeed, in 2003, cyanobacteria were abundant in winter and spring in Lake Geneva but then decreased during the summer, even though an EHWP occurred during the summer. In Lake Annecy, a decrease in cyanobacteria abundance was also observed during the warm summer of 2003. During the 2007 winter EHWP, an exceptionally high biomass of cyanobacteria was observed in all three lakes (Figure 4B). Cyanobacteria maintained a high abundance throughout the year, resulting in a low contribution to the formation of the PCA axes (Figure 4A). In 2006, cyanobacteria abundance exhibited high annual variability; the 2006 autumn EHWP was associated with a strong increase in cyanobacteria abundance in autumn in 
Table 2. Dominant Genera of Cyanobacteria in Lakes Geneva, Bourget, and Annecy

\begin{tabular}{|c|c|c|c|c|c|c|}
\hline Lakes & Taxa & $\%$ Total & \% Spring 2003 & \% Summer 2003 & \% Autumn 2006 & \% Winter 2007 \\
\hline \multirow[t]{8}{*}{ Geneva } & Planktothrix & 42 & 75 & 51 & 66 & 97 \\
\hline & Aphanizomenon & 18 & 19 & 14 & 34 & 2 \\
\hline & Aphanocapsa & 15 & 2 & 5 & 0 & 0 \\
\hline & Psuedanabaena & 14 & 2 & 25 & 1 & 1 \\
\hline & Aphanothece & 4 & 0 & 0 & 0 & 0 \\
\hline & Oscillatoria & 2 & 0 & 0 & 0 & 0 \\
\hline & Pannus & 1 & 0 & 0 & 0 & 0 \\
\hline & Others & 3 & 2 & 5 & 0 & 0 \\
\hline \multirow[t]{4}{*}{ Bourget } & Planktothrix & 85 & & & 97 & 99 \\
\hline & Aphanocapsa & 9 & & & 1 & 0 \\
\hline & Aphanizomenon & 3 & & & 1 & 1 \\
\hline & Others & 3 & & & 1 & 0 \\
\hline \multirow{5}{*}{ Annency } & Aphanocapsa & 72 & 43 & 33 & 25 & 46 \\
\hline & Chroococcus & 19 & 40 & 63 & 69 & 41 \\
\hline & Aphanothece & 3 & 0 & 0 & 0 & 10 \\
\hline & Psuedanabaena & 3 & 17 & 0 & 0 & 3 \\
\hline & Others & 3 & 0 & 4 & 7 & 0 \\
\hline
\end{tabular}

The contribution of each dominant taxa to total cyanobacteria biomass is indicated as a percentage. Percentages are given for the study period (\% TOTAL), and for each EHWP (\% SPRING 2003, \% SUMMER 2003, \% AUTUMN 2006, and \% WINTER 2007).

Lakes Geneva and Bourget (Figure 4B). In Lake Annecy, there was a high biomass at the beginning of the year but it was not maintained for the rest of the year. In this lake cyanobacteria were observed at a very low abundance during the autumn EHWP (Figure 4B).

\section{Influence of EHWP on Seasonal Phytoplankton Composition}

During the warm winter 2007, cyanobacteria showed high abundances in all three lakes and contributed substantially to total phytoplankton abundance in Lakes Geneva and Annecy (Figure 5). The results of the between-group PCA underscored the peculiarity of 2007 that was segregated on axis I during winter in both Lakes Geneva and Bourget (Figure 6A). Cyanobacteria and Zygophyceae had a strong contribution to that axis. In Lake Annecy, 2007 was also associated with cyanobacteria, although this year was close to 2004 in the first plane (Figure 6A).

In spring, 2007 remained different from the other years and was still associated with cyanobacteria in Lake Annecy and with cyanobacteria and conjugates (Figure 6B) in the other lakes. Indeed, after the 2007 winter EHWP, cyanobacteria remained abundant and contributed greatly to phytoplankton biomass in all three lakes, but especially in Lakes Bourget and Annecy, where cyanobacteria biomass was exceptionally high (Figure 5). In Lake Geneva the highest abundance and contribution were recorded during the 2003 spring EHWP (Figure 5). In 2003, no data were available for Lake Bourget, although counts for $P$. rubescens suggest a very low biomass (Jacquet and others 2013).

In Lake Geneva, cyanobacteria made a high, but not an exceptional, contribution to phytoplankton biomass in summer 2003. Absolute biomass was low in both lakes Geneva and Annecy. The results of the between-group PCA indicate that phytoplankton composition in 2003 was no different from that in other years (Figure 7A). In Lake Annecy, 2003 belongs to a group of years in which cyanobacteria are present but in very low abundance in summer.

In 2006, autumn biomass of cyanobacteria reached the highest values recorded during the studied period in Lakes Geneva and Bourget (Figure 5). However, Figure 5 indicates a high, but not exceptional, contribution of cyanobacteria to total phytoplankton biomass. Indeed, although there were large differences in cyanobacteria abundance between the years studied, the PCA revealed that the autumn EHWP had no impact on phytoplankton composition, as suggested by Figure 7B, showing that the year 2006 did not segregate from the other years on the first plane.

\section{Drivers of Cyanobacteria Abundance}

We tested for linear and second order polynomial relationships between cyanobacteria biomass and 

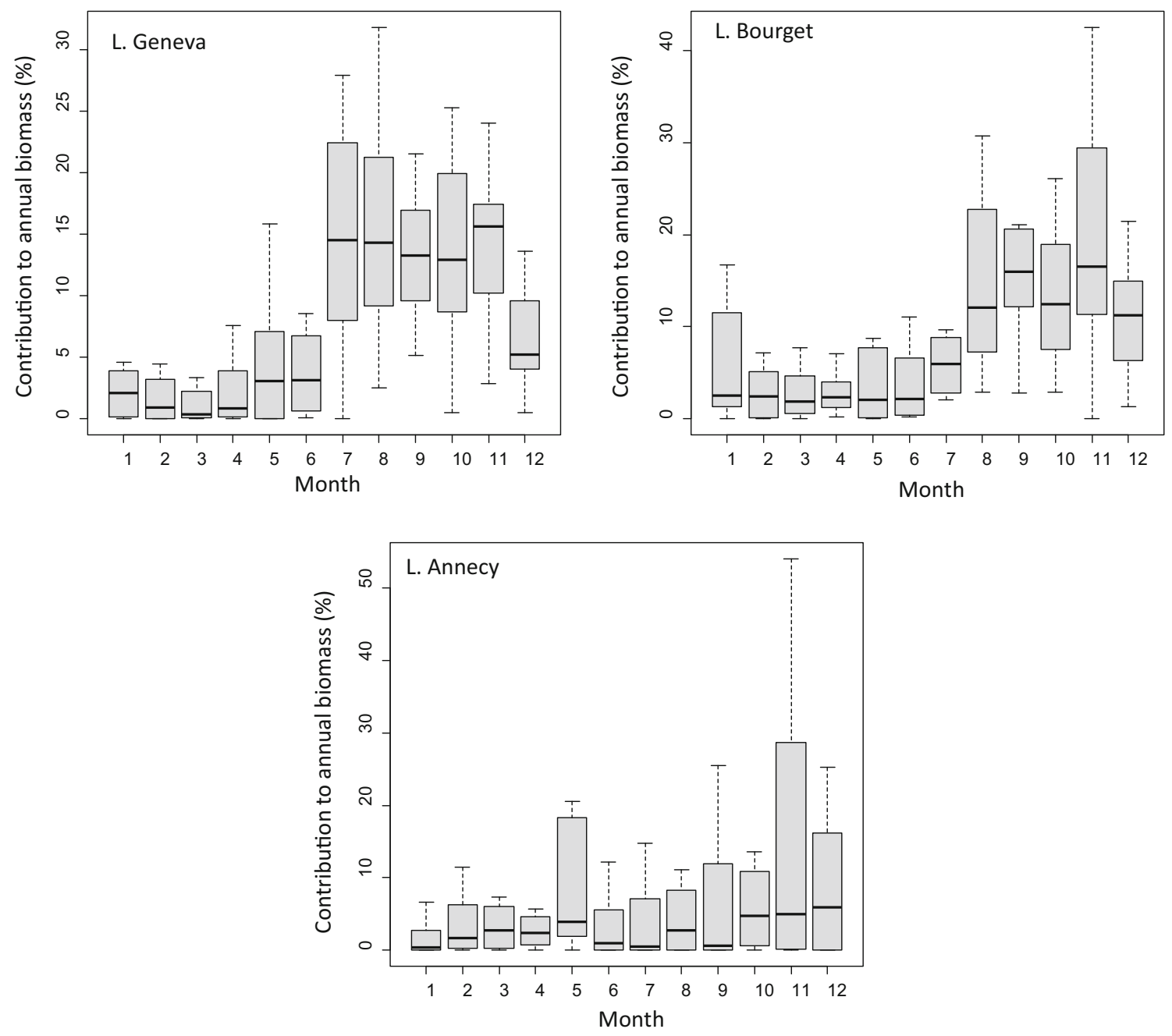

Figure 3. Monthly percentage contributions to the annual cumulative cyanobacteria biomasses in Lakes Geneva, Bourget, and Annecy. Boxes and whiskers, respectively, represent the 25th-75th and 5th-95th percentiles.

phosphorus concentrations, measured in February during the winter mixing. A second order polynomial model fitted the data most closely, indicating a hump-shaped relationship between phosphorus concentration and cyanobacteria abundance in Lakes Geneva and Bourget (Figure 8). Significant relationships between the residual and winter air temperatures were observed for these two lakes $(P$ value $<0.05$; Spearman coefficient, Lake Bourget: rho $=0.809$; Lake Geneva: rho $=0.608$ ). Both in Lake Geneva and Bourget, warm winters were associated with high annual cyanobacteria biomass.

\section{Discussion}

No significant increase was detected in the 2000-2011 temperature measurements considered in this study. This stability in air temperature was also observed at a more global scale and is referred to as a "global warming hiatus". This hiatus can be attributed to a weather pattern in the Pacific associated with the La Nina phase of the El Nino phenomenon (Kosaka and Xie 2013).Our study period was, however, characterized by the occurrence of some hot extreme weather events, some of which have also been identified over the longer reference period of 1971-2000 (Gallina 2012) and at a more global scale: a warm winter in 2007 (Straile and others 2010), a warm summer in 2003 (Jankowski and others 2006; Jöhnk and others 2008; Huber and others 2010). Such convergence in the identification of the extreme meteorological conditions support the relevance of the EHWPs identified in our study and which resulted in the warmest seasons ever observed in central Europe in the past 30 years.

Regional extreme weather and climate events, such as heat waves, heavy precipitation, droughts 

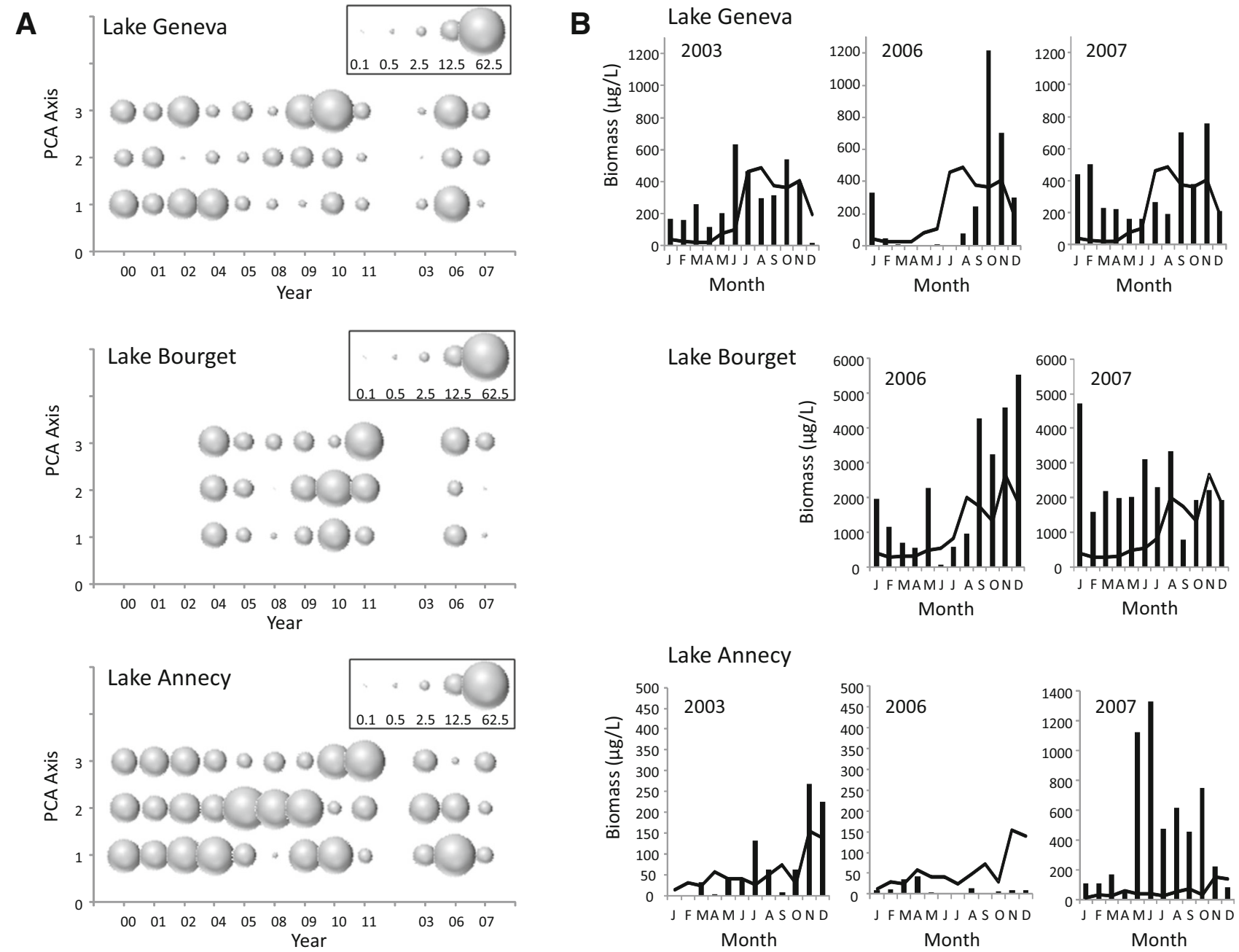

Figure 4. A Percentage of the relative contribution of cyanobacteria to the formation of the PCA axis. The size of the circle represents the relative strength of the contribution. B Annual changes in monthly biomass of cyanobacteria during years with an EHWP (bar) compared to the mean annual pattern of cyanobacteria abundance during years without an EHWP (line).

and wind storms, have a great impact on both ecosystems and human society. For example, heat waves, whose frequency and intensity are likely to increase through the twenty-first century (Beniston and others 2007; Kirtman and others 2013), are now being carefully considered in the framework of global warming (Cubasch and others 2013). In general, extreme weather events are emerging as one of the most important facets of climate change. Consequently, analyzing the effect of EHWPs might be used to investigate past impacts of climate warming on ecosystems. However, despite the growing interest in the impact of extreme events (Jentsch and others 2007), few studies have analyzed their impacts on cyanobacteria abundance, a taxonomic group which is expected to be favored by global warming (Pearl and Huisman 2008).
This research aims to address this lack by focusing on the annual dynamics and inter-annual variability of cyanobacteria in response to EHWPs. We have chosen to sequence the years into seasonal periods to examine the variability in the ecological response to EHWPs (Huber and others 2010). Finally, contrary to Gallina and others (2011), who analyzed the impact of extreme weather events on cyanobacteria at the larger scale of European alpine lakes, we focused on a few lakes located in the same ecoregion (Jacquet and others 2012). Although our results may be less powerful in terms of generalizability, our approach in which each lake is analyzed separately, means the results can be synthesized and interpreted based on the biotic and abiotic properties specific to each lake. This approach enables us to better formulate 

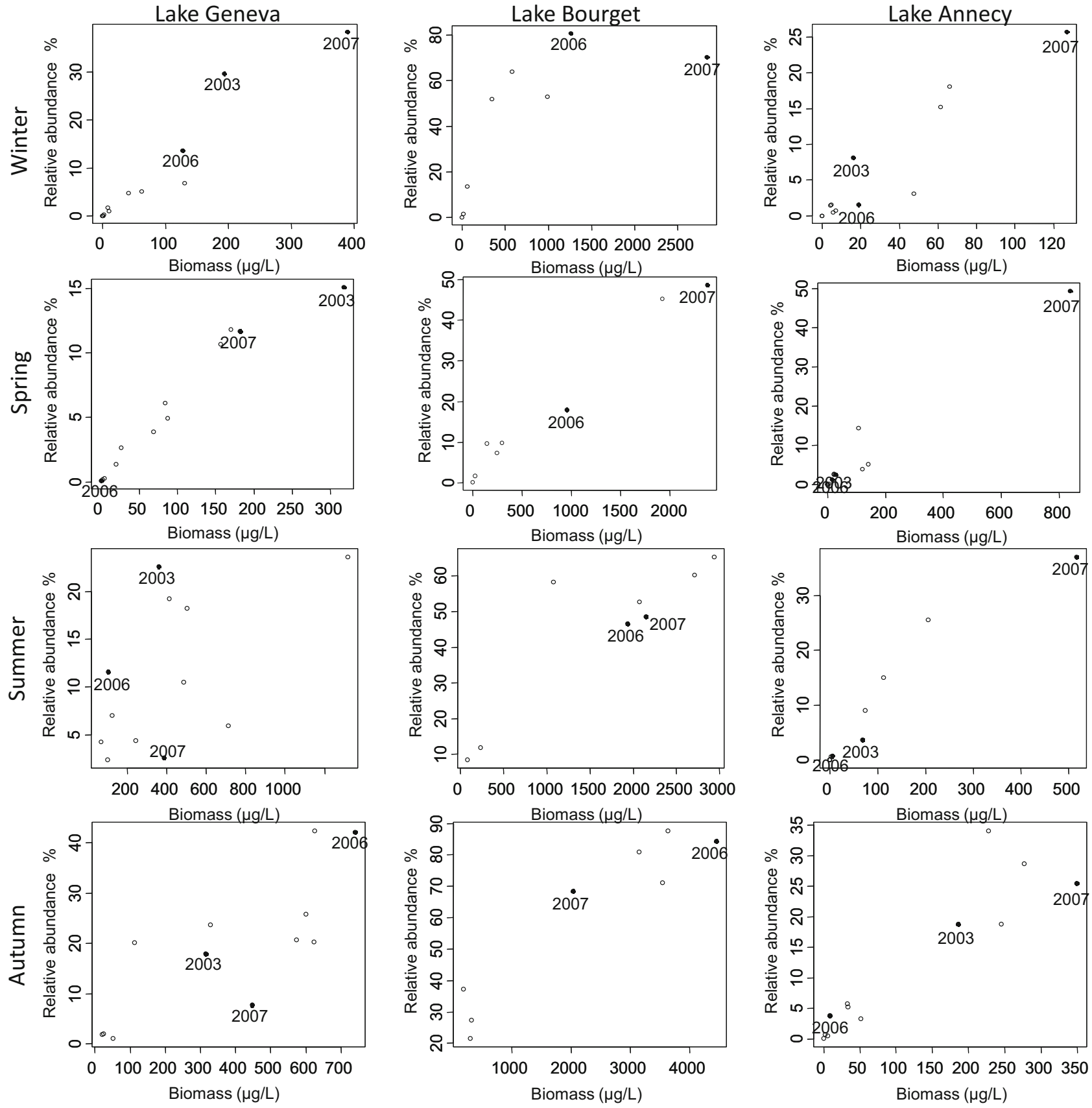

Figure 5. Interannual comparisons of the contribution of cyanobacteria to total phytoplankton biomass (as a percentage) versus absolute biomass of cyanobacteria in Lakes Geneva, Bourget, and Annecy by season.

hypotheses to explain variability between sites that differ in morphology, trophic status, and composition of the cyanobacterial community.

\section{Importance of Nutrients and Trophic State}

Based on the criteria of the European Water Framework Directive, according to the Austrian BI and German PSI indices, the species composition of the phytoplankton community indicates that Lake Annecy, an ultra-oligotrophic lake, is of good ecological quality (Kaiblinger and others 2009). Its cyanobacteria abundance was low compared to that of Lakes Geneva or Bourget, and in terms of cyanobacteria assemblages' composition, Lake Annecy is mainly characterized by the presence of Chroococcales, whereas the cyanobacteria com- 
A
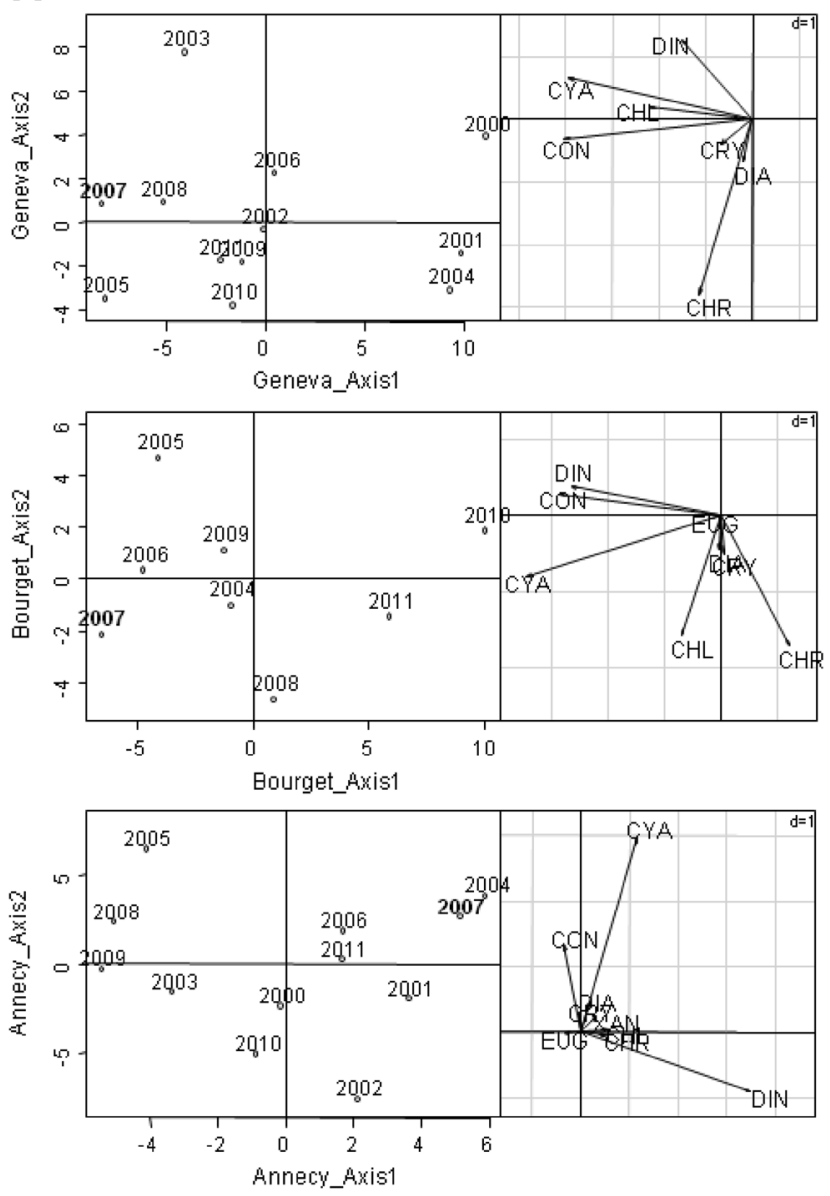

B

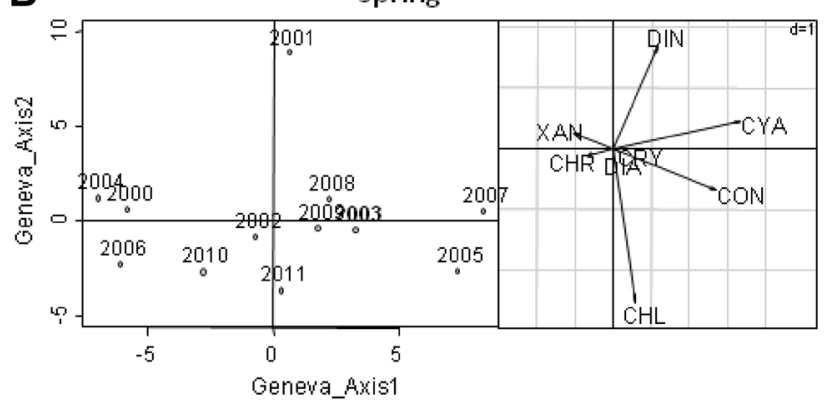

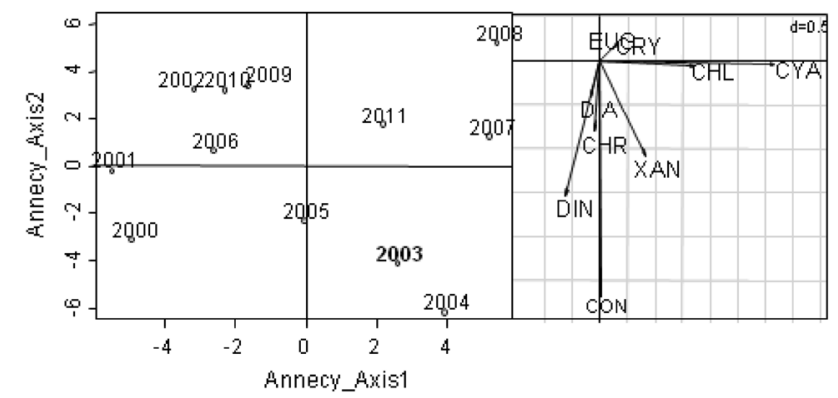

Figure 6. Distribution of the center of gravity of years for winter $(\mathbf{A})$ and spring $(\mathbf{B})$ within the first plane (defined by axes I and II) from the between-group PCA run separately on data from Lakes Geneva, Bourget, and Annecy. Warm years are indicated in bold text. Right hand side of each panel shows the scores of the phytoplankton taxa on the associated factorial map, indicating the contribution of the taxa to the formation of the axes. Abbreviations for phytoplankton taxa are: $C O N$ Zygophyceae, CHL Chlorophyceae, DIA Diatomophyceae, XAN Xanthophyceae, CHR Chrysophyceae, EUG Euglenophyceae, CRY Cryptophyceae, DIN Dinophyceae, CYA Cyanobacteria.

munity in Lakes Bourget and Geneva, is comprised mainly of Oscillatoriales and Nostocales. Although for the mesotrophic Lakes Bourget and Geneva, we observed a relationship between cyanobacteria and phosphorus concentrations, no such relationship was found for Lake Annecy. This may be explained by the fact that in Lake Annecy, phosphorus concentrations were low and did not change substantially during the study period (Jacquet and others 2014a). In Lake Geneva and Bourget, the relationship between phosphorus and cyanobacteria was hump-shaped. In these lakes, the cyanobacteria community was dominated by $P$. rubescens. Such a relationship supports the finding that the proliferation of $P$. rubescens is greatest in meso to moderately eutrophic conditions (Dokulil and Teubner 2012; Jacquet and others 2014b). Indeed, this species is used in the European Water Framework
Directive as an indicator of medium quality state (Brettum 1989), as opposed to other species like Microcystis or Limnothrix redeckei, which are associated with very rich nutrient habitats (Brettum 1989). Such a habitat preference may explain the long-term dynamics of $P$. rubescens in Lake Bourget. $P$. rubescens appeared in the middle of the last century when phosphorus concentrations started to increase (Laurent 1970), then decreased strongly at the height of eutrophication, formed blooms again in the late 1990s, and finally collapsed in recent years (Jacquet and others 2014b). Finally, in the lakes where phosphorus concentrations were high enough to support a $P$. rubescens population, winter air temperature was the second driver of its abundance. This relationship between $P$. rubescens and winter air temperatures suggests that mild winters and winter EHWPs have a positive impact on this 
A
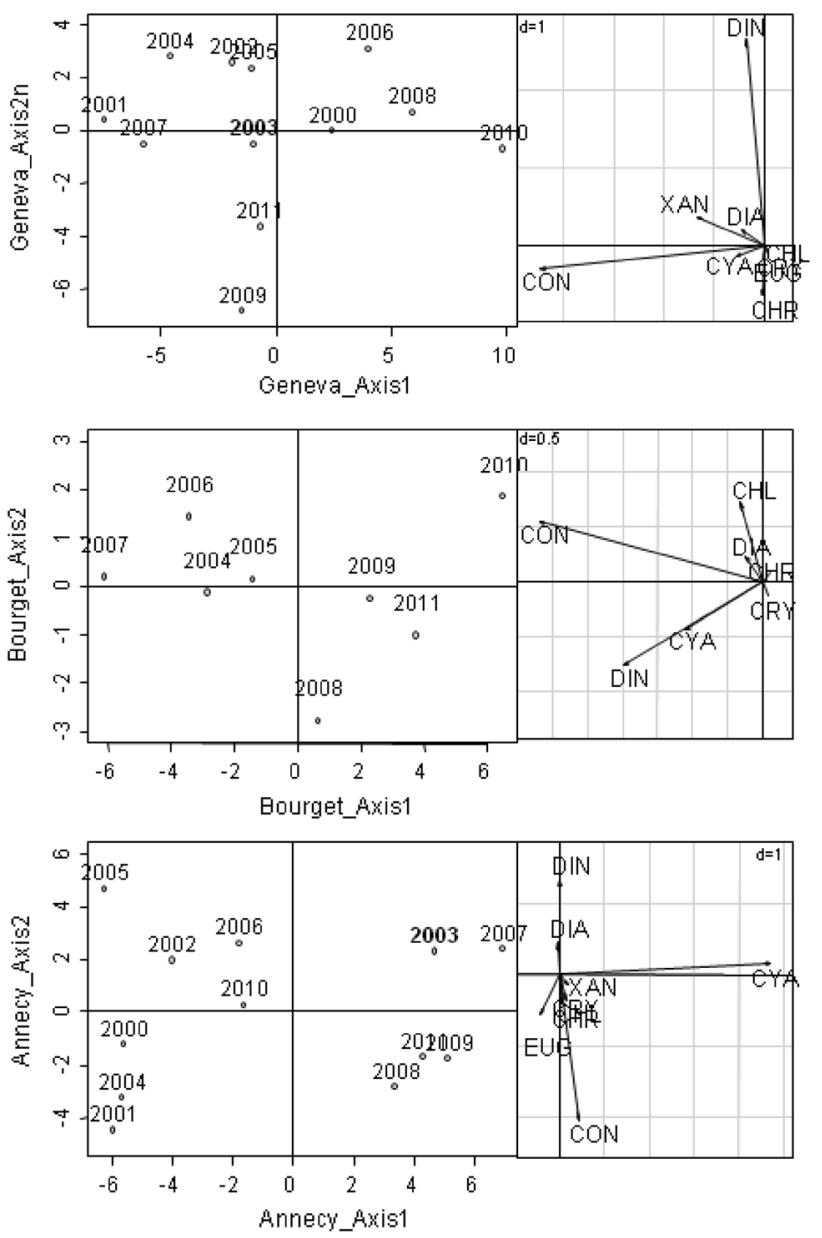

B
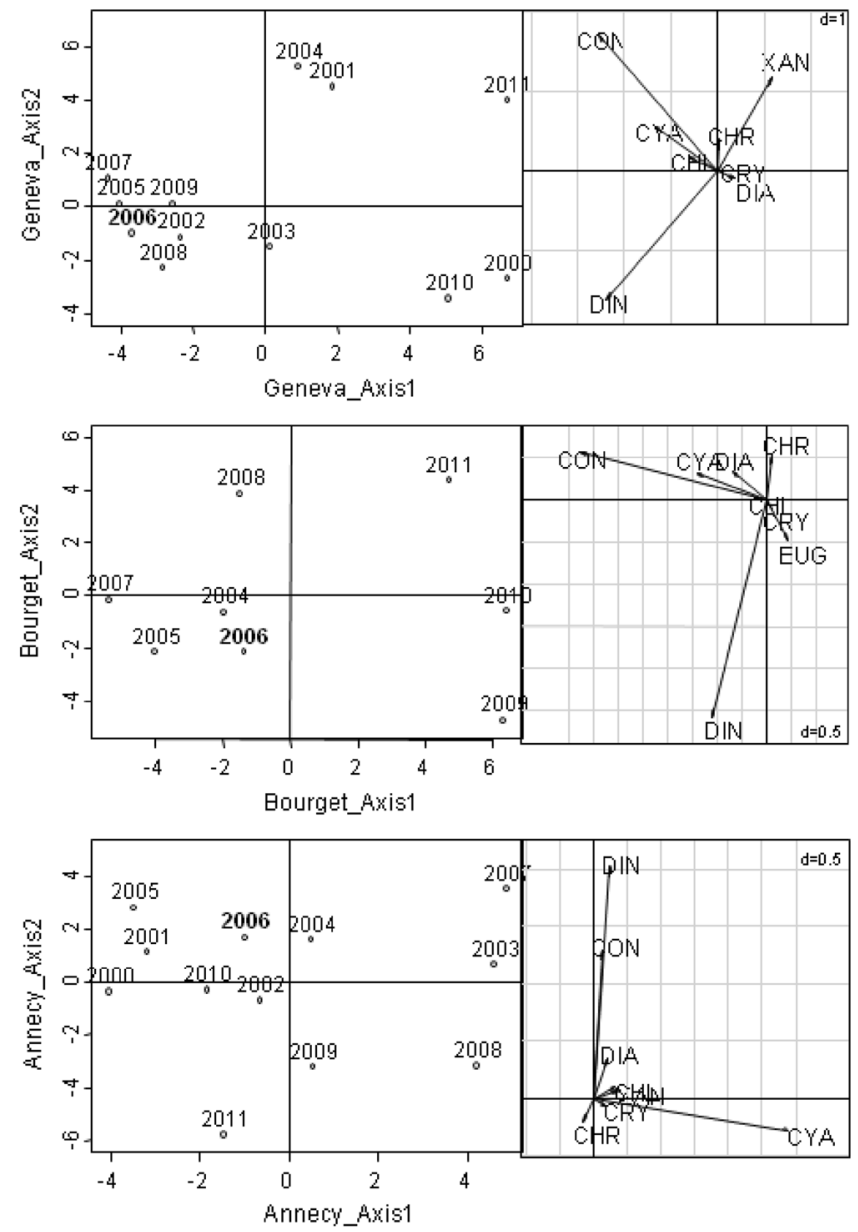

Figure 7. Distribution of the center of gravity of years for summer $(\mathbf{A})$ and autumn $(\mathbf{B})$ within the first plane (defined by axes I and II) from the between-group PCA run separately on data from Lakes Geneva, Bourget, and Annecy. Warm years are indicated in bold text. Right hand side of each panel shows the scores of the phytoplankton taxa on the associated factorial map, indicating the contribution of the taxa to the formation of the axes. Abbreviations for phytoplankton taxa are: CON Zygophyceae, CHL Chlorophyceae, DIA Diatomophyceae, XAN Xanthophyceae, CHR Chrysophyceae, EUG Euglenophyceae, CRY Cryptophyceae, DIN Dinophyceae, CYA Cyanobacteria.

population (Anneville and others 2004; Jacquet and others 2005; Dokulil and Teubner 2012; Jacquet and others 2014b).

\section{The Impacts of Exceptionally Hot Meteorological Conditions are Season Dependant}

The importance in the timing of meteorological events has already been underlined (Huber and others 2010), and our observations support this assertion: according to our findings, the impact of an EHWP depends on the season in which it occurs. Our results show that phytoplankton composition is particularly sensitive to the winter EHWP. In our analysis, a year characterized by an extreme warm winter was associated with a high cyanobacteria biomass and high proportion of cyanobacteria in the phytoplankton community during winter (Table 3). In short, a winter EHWP favored cyanobacteria abundance during winter in the three lakes studied. In Lakes Geneva and Bourget, according to the priority effects (Louette and De Meester 2007) and the idea that past events play an important role in structuring communities (Drake 1991), the high abundance of cyanobacteria probably resulted from the extremely high biomass that occurred during the warm autumn 2006. The following mild winter may have served to maintain this population. Furthermore, our results show that favorable conditions during the winter can impact cyanobacteria abundance right through into spring. Indeed, the 
A

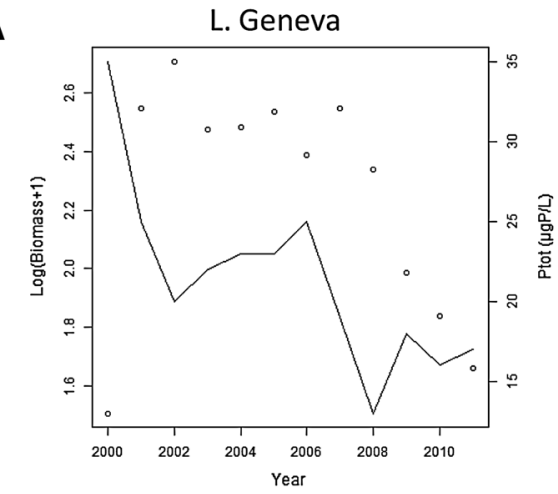

B

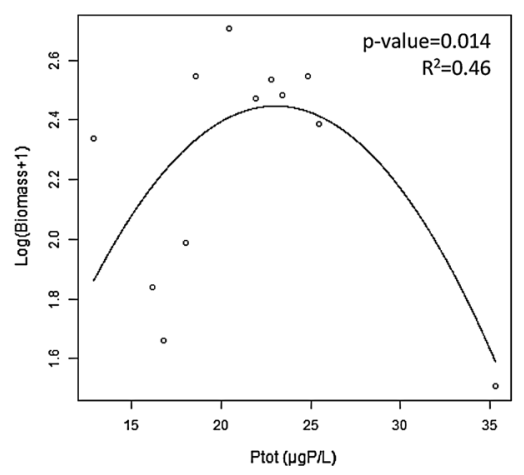

C

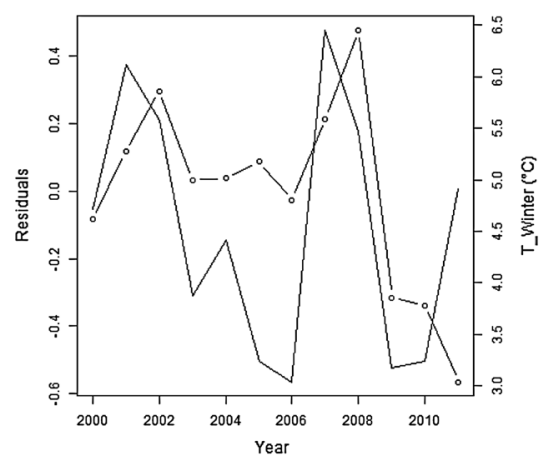

L. Bourget
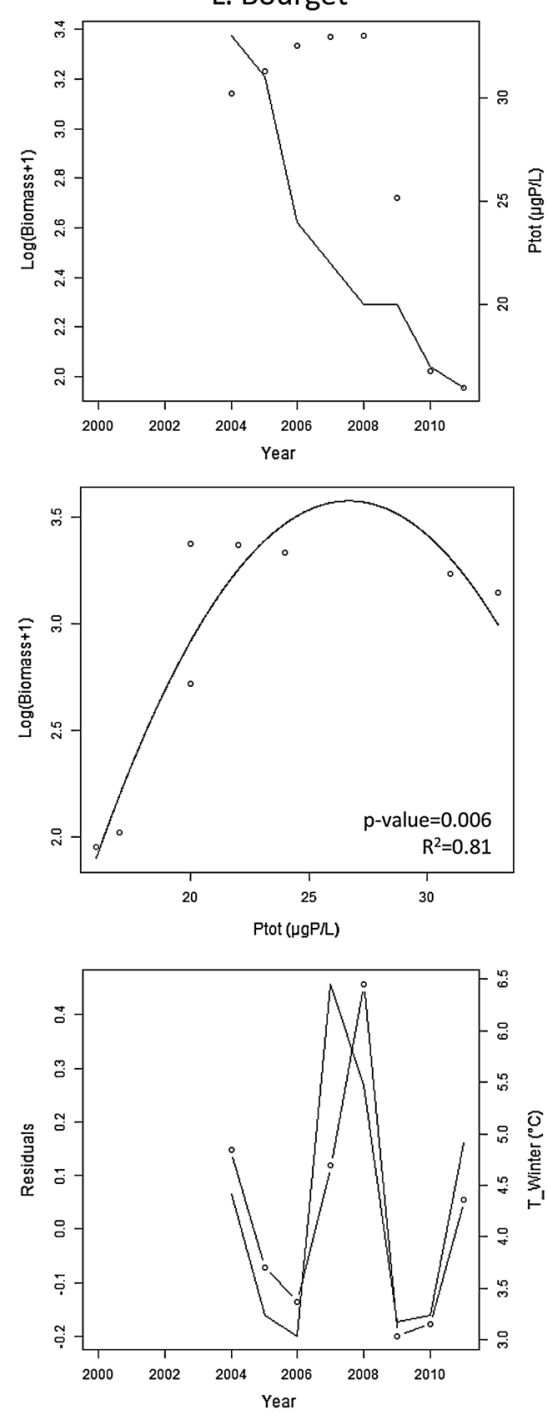

L. Annecy
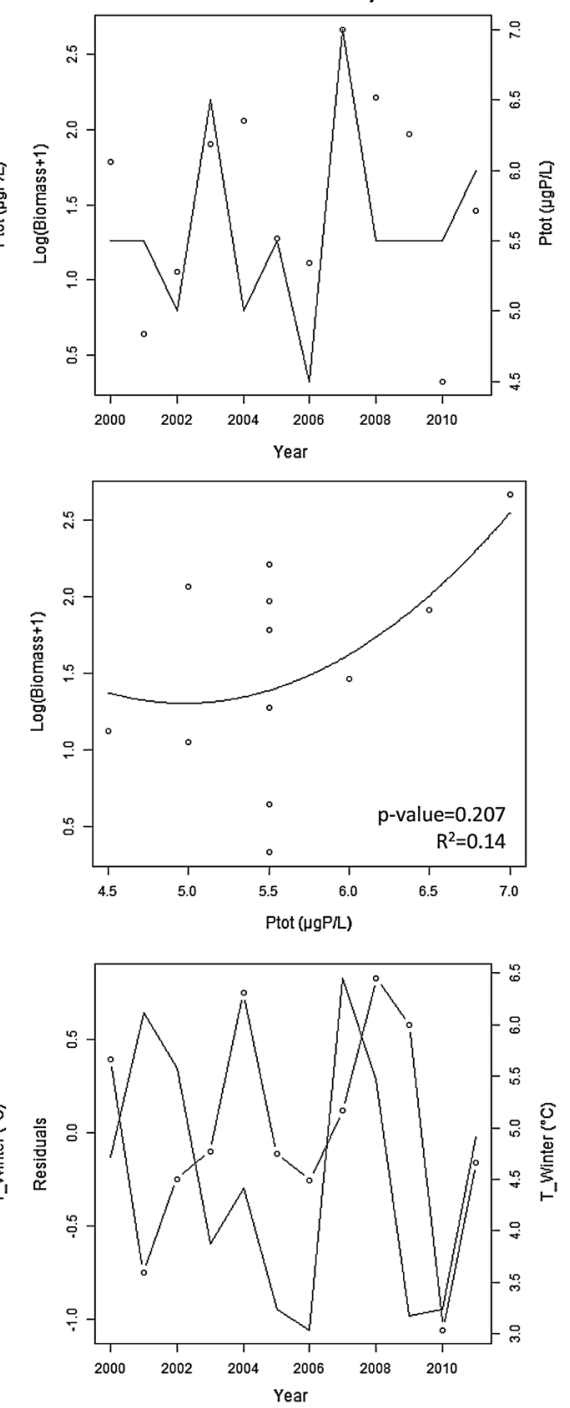

Figure 8. A Long-term changes in cyanobacteria abundance (dots) and total phosphorus concentrationmeasured in February (line). B Relationship between phosphorus and annual cyanobacteria biomass. C Long-term changes in the residuals of the relationship between cyanobacteria and phosphorus (dotted line), and long-term changes in winter water temperature (solid line).

Table 3. The Impact of EHWPs on Cyanobacteria (Summary of Results Presented in Figures 4, 5, 6, 7)

\begin{tabular}{|c|c|c|c|c|c|c|c|c|c|c|c|c|}
\hline \multirow[b]{2}{*}{ Lake Geneva } & \multicolumn{3}{|c|}{ Spring EHWP (2003) } & \multicolumn{2}{|c|}{$\begin{array}{l}\text { Summer } \\
(2003)\end{array}$} & \multirow{2}{*}{$\begin{array}{c}\text { EHWP } \\
-\end{array}$} & \multicolumn{3}{|c|}{$\begin{array}{l}\text { Autumn EHWP } \\
(2006)\end{array}$} & \multicolumn{2}{|c|}{$\begin{array}{l}\text { Winter } \\
(2007)\end{array}$} & \multirow{2}{*}{$\begin{array}{r}\text { EHWP } \\
\mathrm{C}\end{array}$} \\
\hline & B & $\mathrm{C} \%$ & - & - & - & & B & - & - & B & $\mathrm{C} \%$ & \\
\hline Lake Bourget & NA & NA & NA & NA & NA & NA & B & - & - & B & - & $\mathrm{C}$ \\
\hline Lake Annecy & - & - & - & - & - & - & - & - & - & B & $\mathrm{C} \%$ & $\mathrm{C}$ \\
\hline
\end{tabular}

" $B$ " indicates an effect on cyanobacteria biomass, "C\%" indicates an effect on the relative contribution of cyanobacteria to total phytoplankton biomass, and " $\mathrm{C}$ " indicates an effect on phytoplankton composition. "NA" indicates no data were available. 
literature suggests that warm winters favor $P$. rubescens(Anneville and others 2004; Jacquet and others 2005; Dokulil and Teubner 2012; Jacquet and others 2014b) because this organism's success is related to the timing of the onset of stratification (Dokulil and Teubner 2012) and the depth of winter mixing, which in turn influences spring inoculum abundance (Walsby and others 1998). Inoculum is known to play an important role in structuring the community; the species already present in largest numbers because they had the largest residual population from the previous episode, or were recruited by germination of the greatest number of resting propagules, are likely to become prominent after stabilization of a deep-mixed water column (Reynolds 1999). Our result strongly supports the concept of ecological memory (Padisak 1992), defined as the capacity of the ecosystem or its experiences from past states to influence present or future responses of the community. Ecological memory can involve various mechanisms and it can be the manifestation of priority effects, according to which temporal priority of a species may confer a competitive advantage over other taxa (Hodge and others 1996). To resume, our results put forward that the successions of events may have considerable implications for the abundance of phytoplankton taxa and they suggest that phytoplankton communities appear as historically derived structures. In Lake Annecy, cyanobacteria were not abundant in autumn 2006. However, they reached a high biomass in winter 2007, when the cyanobacteria community was dominated by Aphanocapsa, Aphanothece, and Chroococcus. Aphanocapsa abundance increased and managed to dominate throughout the year. Aphanocapsa is quite ubiquitous and some papers have reported its ability to use organic compounds (Beauclerk and Smith 1978). Thus, the mixotrophic capacities of these taxa may explain their presence in Lake Annecy, a strongly phosphorus-limited ecosystem. We have shown that a warm spring had a positive effect on cyanobacteria in Lake Geneva; unfortunately, we have no data comparable to the data from the other years for Lake Bourget. In Lakes Geneva and Annecy, the summer EHWP did not promote blooms and did not favor cyanobacteria over other taxa. During the monitoring of Lake Bourget, a very low biomass of cyanobacteria was reported for summer 2003 (Jacquet and others 2013; Vinçon-Leite 2014). These results differ from that of Jöhnk and others (2008); they showed that the 2003 summer heat wave had a strong influence on water temperature and hydrodynamics, boosting the growth of cyanobacteria and shifting the competitive balance in favor of buoyant cyanobacteria. Such contrasting results may be due to differences between the lakes in morphology, nutrient availability, and dominant cyanobacterial taxa. The three lakes we studied have much lower phosphorus concentrations, different stratification dynamics due to their greater depth $\left(Z_{\max }=30 \mathrm{~m}\right.$ in Jöhnk and others vs. $Z_{\max }=65 \mathrm{~m}$ in Lake Annecy, the shallowest of our three lakes) and different morpho-functional properties of the dominant cyanobacterial forms. An increase in air temperature intensifies stratification (Livingstone 2003; Kerimoglu and Rinke 2013), which, in deep water bodies, can result in a substantial reduction in nutrient replenishment in the surface layer and lead to a decrease in primary production, especially if the intensified stratification leads to incomplete mixing during winter (Straile and others 2010). Historical and paleolimnological data suggest that climate change has contributed to diminished productivity (O'Reilly and others 2003). Furthermore, the cyanobacteria consist of many different species exhibiting a great diversity of traits and physiological characteristics. Different cyanobacteria species would be expected to respond in different ways to changes in environmental conditions (Rigosi and others 2014). In Lakes Bourget and Geneva, where the cyanobacterial community was dominated by $P$. rubescens (Table 2), our findings are in agreement with other authors who have observed a decline of the $P$. rubescens population in Lake Zurich (Posch and others 2012) and low $P$. rubescens biomasses in Muggelsee (Huber and others 2012) during the extremely hot 2003 summer. Finally, our results illustrate that an autumn EHWP can promote cyanobacterial growth in mesotrophic lakes (Table 3). It impacts cyanobacteria biomass but not the composition of the phytoplankton community. This would suggest that milder autumn temperatures benefit the entire phytoplankton community rather than just cyanobacteria. Gallina and others (2011) found similar results, and they hypothesized that lake temperature must reach a critical threshold to induce a change in phytoplankton composition. An autumn EHWP has no effect on oligotrophic lakes, probably because phosphorus concentrations are not high enough to support high phytoplankton biomass in this type of lake.

Impacts of Exceptional Hot Weather Periods are Informative But Unlikely to be Used to Forecast Future Changes in Cyanobacteria Abundances

Model projections for the temperate climatic zone point to higher air temperatures, increased stability 
of the water column, increased duration of the stratified period, and a reduction in vertical turbulent mixing. In such a habitat, the eco-physiological properties of some cyanobacteria species should enable them to maintain and out-compete other phytoplankton taxa (Carey and others 2012). Indeed, at relatively high temperatures, the growth rate of cyanobacteria typically reaches an optimum where other groups are severely inhibited (Butterwick and others 2005; Jöhnk and others 2008), and many cyanobacteria can regulate their position in the water column and so resist intensified stratification and exploit nutrients reaching metalimnic layers. Finally cyanobacteria may benefit from an increase in the duration of their optimal growth period. All in all, global warming is anticipated to favor cyanobacteria. However, there are a few caveats to keep in mind. First, it is unlikely that all cyanobacteria will respond in the same way to global warming, and taking the cyanobacteria as a group rather than considering species individually may bias our interpretation. Second, phosphorus runoff and availability may act in combination with internal loading and lake morphology to mediate the effect of EHWPs on cyanobacteria.

Our results suggest that EHWPs can be used to study past impacts of global warming. Extreme meteorological conditions are a way to track the consequences of warming during a period in which there is no increase in air temperature. They can be used at a large scale to identify exceptional years for inter-lake comparisons. Our results provide evidence that air temperature has an impact on cyanobacteria biomass in deep peri-alpine lakes (Gallina and others 2011) and supports the claim that climate change favors some phytoplankton taxa over others. But we have also showed that the timing of the EHWP is crucial and so it may not always favor cyanobacteria. Furthermore the impact of an EHWP can extend through several seasons and thereby influence the annual succession of communities. Such a constraint from historical states supports the concept of ecological memory, which has been shown to be important in shaping phytoplankton dynamics in aquatic ecosystems (Padisak 1992).

As recent record temperatures have been comparable to temperatures in a greenhouse climate (Beniston 2007), various authors have suggested using EHWPs as a tool for forecasting future impacts (Jankowski and others 2006; Gallina and others 2011) but Straile and others (2010) showed that direct extrapolations can be misleading, as the sequence of meteorological events are also relevant. Furthermore, ecological memory and sensitivity to nutrient concentrations are two properties of aquatic ecosystems that are crucial constraints on this approach. Furthermore, in deep aquatic ecosystems, reduced winter mixing reduces euphotic layer fertilization with deep water (O'Reilly and others 2003). Consequently, extreme events that occur today cannot be expected to occur under the same conditions in the future, nor have the same impacts on a phytoplankton community whose structure has been shown to be influenced by past events. Thus, extreme events are not suitable for predicting the future abundance of cyanobacteria; nor can they be used as proxy for forecasting future effects on the phytoplankton community.

\section{What is the Future for Cyanobacteria in a Warmer World?}

Our study did not provide any evidence that higher summer air temperatures promote cyanobacterial growth (Table 3). However, this does not mean that some cyanobacteria taxa will not in fact proliferate more than others in such a situation. To better address this issue, future research should (i) take into account changes in the watershed that could potentially impact runoff and future phosphorus availability, and (ii) consider individual cyanobacteria species rather than the cyanobacteria as one homogeneous group. For example, one could distinguish among cyanobacteria based on shape and/or size, or focus on picocyanobacteria, which are expected to be favored by a temperature increase and nutrient decrease (Callieri 2008, 2010). In general, nutrient limiting conditions are expected to favor picocyanobacteria over larger phytoplankters (Agawin and others 2000). Indeed, the relative contribution of picocyanobacteria to total phytoplankton abundance has been shown to increase with decreasing trophic state (Agawin and others 2000). In addition, increased summer temperatures, combined with lowered soluble reactive phosphorus levels, could provide picocyanobacteria with an ecological advantage over other phytoplankton classes in various aquatic systems, including lakes (Agawin and others 2000; Collos and others 2009; Fu and others 2007). However, it is still difficult to disentangle the effects of reoligotrophication and concomitant global warming in the response of lacustrine picocyanobacteria, partly due to the lack of long-term monitoring data (Jacquet and others 2013). A recent study based on a DNA-paleolimnological approach suggested a significant effect of summer temperature on picocyanobacteria dynamics in Lake Bourget (Domaizon and others 2013). In light of this result, we 
emphasize the need to analyze picocyanobacteria, which is not regularly monitored and often excluded from the majority of long-term monitoring programs. Finally, there is still a great challenge in understanding how the combined effects of the drivers (nutrient supply rates, light, temperature, oxidative stressors, interactions with other biota) impact cyanobacteria blooms and cyanotoxin production (Pearl and Otten 2013), and the diversity of responses of native and invasive cyanobacteria species to local and global drivers has to be taken into account to better understand the impact of climate change on these communities.

\section{ACKNOWLEDGEMENTS}

Data for Lake Geneva, Lake Annecy, and Lake Bourget were collected as part of regular sampling carried out by the CIPEL, SILA, and CISALB, respectively. This paper is a contribution to the SOERE OLA. O. K. was funded by the University of Savoie.

\section{REFERENCES}

Adrian R, Deneke R, Mischke U, Stellmacher R, Lederer P. 1995. Long-term study of the Heiligensee (1975-1992)—evidence for effects of climatic-change on the dynamics of eutrophied lake ecosystems. Archiv für Hydrobiologie 133:315-37.

Adrian R, O'Reilly CM, Zagarese H, Baines SB, Hessen DO, Keller W, Livingstone DM, Sommaruga R, Straile D, Van Donk E, Weyhenmeyer GA, Winder M. 2009. Lakes as sentinels of climate change. Limnol Oceanogr 54:2283-97.

AFNOR. 2006. NF EN 15204. Qualité de l'eau-Norme guide pour le dénombrement du phytoplancton par microscopie inversée (méthode Utermöhl). Afnor. 41 pp.

Agawin NRS, Duarte CM, Agustí S. 2000. Nutrient and temperature control of the contribution of picoplankton to phytoplankton biomass and production. Limnol Oceanogr 45:591-600

Alric B, Jenny JP, Berthon V, Arnaud F, Pignol C, Reyss JL, Sabatier P, Perga ME. 2013. Local forcings affect lake zooplankton vulnerability and response to climate warming. Ecology 94:2767-87.

Anneville O, Molinero JC, Souissi S, Gerdeaux D. 2010. Seasonal and interannual variability of cladoceran communities in two peri-alpine lakes: uncoupled response to the 2003 heat wave. J Plankton Res 32:913-25.

Anneville O, Souissi S, Gammeter S, Straile D. 2004. Seasonal and inter-annual scales of variability in phytoplankton assemblages: comparison of phytoplankton dynamics in three peri-alpine lakes over a period of 28 years. Freshw Biol 49:98-115.

Anneville O, Souissi S, Ginot V, Ibanez F, Druart J-C, Angeli N. 2002. Temporal mapping of phytoplankton assemblages in Lake Geneva: annual and interannual changes in their patterns of succession. Limnol Oceanogr 47:1355-66.
Arheimer B, Andreasson J, Fogelberg S, Johnsson H, Pers CB, Persson K. 2005. Climate change impact on water quality: model results from southern Sweden. Ambio 34:559-66.

Beauclerk AA, Smith AJ. 1978. Transport of D-glucose and 3-Omethyl-D-glucose in the cyanobacteria Aphanocapsa 6714 and Nostoc strain Mac. Eur J Biochem 82:187-97.

Beaulieu M, Pick F, Gregory-Eaves I. 2013. Nutrients and water temperature are significant predictors of cyanobacterial biomass in a 1147 lakes data set. Limnol Oceanogr 58:1736-46.

Beniston M. 2007. Entering into the "greenhouse century": recent record temperatures in Switzerland are comparable to the upper temperature quantiles in a greenhouse climate. Geophys Res Lett 34:L16710. doi:10.1029/2007GL030144.

Beniston M, Stephenson DB, Christensen OB, Ferro CAT, Frei C, Goyette S, Halsnaes K, Holt T, Jylha K, Koffi B, Palutikof J, Schoell R, Semmler T, Woth K. 2007. Future extreme events in European climate: an exploration of regional climate model projections. Clim Chang 81:71-95.

Berthon V, Marchetto A, Rimet F, Dormia E, Jenny JP, Pignol C, Perga ME. 2013. Trophic history of French sub-Alpine lakes over the last similar to 150 years: phosphorus reconstruction and assessment of taphonomic biases. J Limnol 72:417-29.

Bourrelly P. 1972. Les algues d'eau douce, Tome II: Les algues jaunes et brunes. Paris: N. Boubée et Cie. pp 1-572.

Bourrelly P. 1981. Les algues d'eau douce, Tome II: Les algues jaunes et brunes. Paris: N. Boubée et Cie. pp 1-517.

Bourrelly P. 1985. Les algues d'eau douce, Tome III: Les algues bleues et rouges. Paris: N. Boubée et Cie. pp 1-606.

Brettum P. 1989. Algen als Indikatoren für die Gewässerqualität in norwegischen Binnenseen [Translation from Norvegian, Meier B.G., 2000]. Oslo: Norsk Institutt for vannforskning (NIVA). p 102.

Butterwick C, Heaney SI, Talling JF. 2005. Diversity in the influence of temperature on the growth rates of freshwater algae, and its ecological relevance. Freshw Biol 50:291-300.

Callieri C. 2008. Picophytoplankton in freshwater ecosystems: the importance of small-sized phototrophs. Freshwater reviews 1:1-28.

Callieri C. 2010. Single cells and microcolonies of freshwater picocyanobacteria: a common ecology. J Limnol 69:257-77.

Carey CC, Ibelings BW, Hoffmann EP, Hamilton DP, Brookes JD. 2012. Eco-physiological adaptations that favour freshwater cyanobacteria in a changing climate. Water Res 46:1394-407.

Cubasch U, Wuebbles D, Chen D, Facchini MC, Frame D, Mahowald N, Winther J-G. 2013. Introduction. In: Stocker $\mathrm{TF}$, Qin D, Plattner G-K, Tignor M, Allen SK, Boschung J, Nauels A, Xia Y, Bex V, Midgley PM, Eds. Climate change 2013: the physical science basis. Contribution of Working Group I to the Fifth Assessment Report of the Intergovernmental Panel on Climate Change. Cambridge: Cambridge University Press.

Collos Y, Bec B, Jauzein C, Abadie E, Laugier T, Lautier J, Pastoureaud A, Souchu P, Vaquer A. 2009. Oligotrophication and emergence of picocyanobacteria and a toxic dinoflagellate in Thau lagoon, southern. J Sea Res 61:68-75.

De Senerpont Domis LN, Mooij WM, Huisman J. 2007. Climateinduced shifts in an experimental phytoplankton community: a mechanistic approach. Hydrobiologia 584:403-13.

Dokulil M, Teubner K. 2012. Deep living Planktothrix rubescens modulated by environmental constraints and climate forcing. Hydrobiologia 698:29-46. 
Dolédec S, Chessel D. 1989. Rythmes saisonniers et composantes stationnelles en milieu aquatique II-Prise en compte et élimination d'effets dans un tableau faunistique. Acta Ecologica/Ecologia Generalis 10:207-32.

Domaizon I, Savichtcheva O, Debroas D, Arnaud F, Villar C, Pignol C, Alric B, Perga ME. 2013. DNA from lake sediments reveals the long-term dynamics and diversity of Synechococcus assemblages. Biogeosciences 10:3817-38.

Domaizon I, Perga ME, Rimet F, Guillard J, Savoye L, Jacquet S, Lainé L, Colon M, Hamelet V, Lasne E. 2014. Suivi de la qualité des eaux du lac d'Annecy. In: SILA, Ed. Rapport 2013. INRA-Thonon. 90 pp.

Drake JA. 1991. Community-assembly mechanics and the structure of an experimental species ensemble. Am Nat 137:1-26.

Edwards M, Richardson AJ. 2004. Impact of climate change on marine pelagic phenology and trophic mismatch. Nature 430:881-4.

Ekvall MK, De la Calle MJ, Faassen EJ, Gustafsson S, Lürling M, Hansson LA. 2013. Synergistic and species-specific effects of climate change and water colour on cyanobacterial toxicity and bloom formation. Freshw Biol 58:2414-22.

Elliott JA. 2012. Is the future blue-green? A review of the current model predictions of how climate change could affect pelagic freshwater cyanobacteria. Water Res 46:1364-71.

Fu FX, Warner ME, Zhang Y, Feng Y, Hutchins DA. 2007. Effects of increased temperature and $\mathrm{CO}_{2}$ on photosynthesis, growth, and elemental ratios in marine Synechococcus and Prochlorococcus (Cyanobacteria). J Phycol 43:485-96.

Gallina N. 2012. Description and modeling of phytoplankton with an emphasis of cyanobacteria in deep peri-alpine lakes under warmer climatic conditions. PhD thesis, University of Geneva. 106 pp.

Gallina N, Anneville O, Beniston M. 2011. Impacts of extreme air temperatures on cyanobacteria in five deep peri-alpine lakes. J Limnol 70:186-96.

Hodge S, Arthur W, Mitchell P. 1996. Effects of temporal priority on interspecific interactions and community development. Oikos 76:350-8.

Huber V, Adrian R, Gerten D. 2010. A matter of timing: heat wave impact on crustacean zooplankton. Freshw Biol 55:1769-79.

Huber V, Wagner C, Gerten D, Adrian R. 2012. To bloom or not to bloom: contrasting responses of cyanobacteria to recent heat waves explained by critical thresholds of abiotic drivers. Oecologia 169:245-56.

IPCC. 2001. Climate change 2001: synthesis report-a contribution of Working Groups I, II and III to the Third Assessment Report of the Intergovernmental Panel on Climate Change. Cambridge: Cambridge University Press.

Jacquet S, Briand JF, Leboulanger C, Avois C, Oberhaus L, Tassin B, Vinçon-Leite B, Paolini G, Druart JC, Anneville O, Humbert JF. 2005. The proliferation of the toxic cyanobacterium Planktothrix rubescens following restoration of the largest natural French lake (Lac du Bourget). Harmful Algae 4:651-72.

Jacquet S, Cachera S, Colon M, Girel C, Guillard J, Hamelet V, Hustache J-C, Kerrien F, Lacroix D, Laine L, Laplace-Treyture C, Lazzarotto J, Paolini G, Perga ME, Perney P, Rimet F, Verneaux V. 2013. Suivi environnemental des eaux du lac du Bourget pour l'année 2012. Rapport INRA-CISALB-CALB, 226 pp.

Jacquet S, Domaizon I, Anneville O. 2012. Evolution de paramètres clés indicateurs de la qualité des eaux et du fonctionnement écologique des grands lacs péri-alpins (Léman,
Annecy, Bourget): Etude comparative de trajectoires de restauration post-eutrophisation. Archives des Sciences 65:191-208.

Jacquet S, Domaizon I, Anneville O. 2014a. The need for ecological monitoring of freshwaters in a changing world: a case study of Lakes Annecy, Bourget and Geneva. Environ Monit Assess 186:3455-76. doi:10.1007/s10661-014-3630-z.

Jacquet S, Kerimoglu O, Rimet F, Paolini G, Anneville O. 2014b. Cyanobacterial bloom termination: the disappearance of Planktothrix rubescens from Lake Bourget (France) after restoration. Freshw Biol 59:2472-87. doi:10.1111/fwb.12444.

Jankowski T, Livingstone DM, Bührer H, Forster R, Niederhauser P. 2006. Consequences of the 2003 European heat wave for lake temperature profiles, thermal stability, and hypolimnetic oxygen depletion: implications for a warmer world. Limnol Oceanogr 51:815-19.

Jentsch A, Kreyling J, Beierkuhnlein C. 2007. A new generation of climate-change experiments: events, not trends. Front Ecol Environ 5:365-74.

Jeppesen E, Søndergaard M, Jensen JP, Havens KE, Anneville O, Carvalho L, Coveney MF, Deneke R, Dokulil MT, Foy B, Gerdeaux D, Hampton SE, Hilt S, Kangur K, Köhler J, Lammens EHHR, Lauridsen TL, Manca M, Miracle MR, Moss B, Nõges P, Persson G, Phillips G, Portielje R, Romo S, Schelske CL, Straile D, Tatrai I, Willén E, Winder M. 2005. Lakes responses to reduced nutrient loading-an analysis of contemporary long term data from 35 case studies. Freshw Biol 50:1747-71.

Jeppesen E, Søndergaard M, Jensen JP. 2003. Climatic warming and regime shifts in lake food webs-some comments. Limnol Oceanogr 48:1346-9.

Jöhnk KD, Huisman J, Sharples J, Sommeijer B, Visser PM, Stroom JM. 2008. Summer heatwaves promote blooms of harmful cyanobacteria. Glob Chang Biol 14:495-512.

Kaiblinger C, Anneville O, Tadonleke R, Rimet F, Druart JC, Guillard J, Dokulil MT. 2009. Central European water quality indices applied to long-term data from peri-alpine lakes: test and possible improvements. Hydrobiologia 633:67-74.

Kerimoglu O, Rinke K. 2013. Mixing in polymictic water bodies under varying hydrological and meteorological conditions. Water Resour Res 49:7518-27.

Kirtman B, Power SB, Adedoyin JA, Boer GJ, Bojariu R, Camilloni I, Doblas-Reyes FJ, Fiore AM, Kimoto M, Meehl GA, Prather M, Sarr A, Schär C, Sutton R, Van Oldenborgh GJ, Vecchi G, Wang HJ. 2013. Near-term climate change: projections and predictability. In: Stocker TF, Qin D, Plattner G-K, Tignor M, Allen SK, Boschung J, Nauels A, Xia Y, Bex V, Midgley PM, Eds. Climate change 2013: the physical sciences basis. Contribution of Working Group I to the Fifth Assessment Report of the Intergovernmental Panel on Climate Change. Cambridge: Cambridge University Press.

Kosaka Y, Xie S-P. 2013. Recent global-warming hiatus tied to equatorial Pacific surface cooling. Nature 501:403-7.

Kosten S, Huszar VLM, Bécares E, Costa LS, Van Donk E, Hansson L-A, Jeppesen E, Lacerot G, Kruk C, Mazzeo N, De Meester L, Moss B, Lürling M, Nõges T, Romo S, Scheffer M. 2012. Warmer climate boosts cyanobacterial dominance in shallow lakes. Glob Chang Biol 18:118-26.

Lazzarotto J, Quetin P, Klein A. 2013. Physical-chemical changes in the waters of Lake Geneva (major-elements). Rapport de la Commission Internationale pour la protection des eaux du Léman contre la pollution. Campagne 2012:16-46. 
Laurent P.1970. Étude de la pollution du lac du Bourget, campagne 1969. Rapport INRA-Thonon. p 16.

Livingstone DM. 2003. Impact of secular climate change on the thermal structure of a large temperate central European lake. Clim Chang 57:205-25.

Louette G, De Meester L. 2007. Predation and priority effects in experimental zooplankton communities. Oikos 116:419-26.

Mearns LO, Rosenzweig C, Goldberg R. 1997. Mean and variance change in climate scenarios: methods, agricultural applications, and measures of uncertainty. Clim Chang 35:367-96.

Monod R, Blanc P, Corvi C. 1984. Le régime thermique du Léman. CIPEL, Ed. Le Léman synthèse 1957-1982. Lausanne. p 75-88.

O'Reilly CM, Alin SR, Plisnier PD, Cohen AS, McKee BA. 2003. Climate change decreases aquatic ecosystem productivity of Lake Tanganyika, Africa. Nature 424:766-8.

Padisak J. 1992. Seasonal succession of phytoplankton in a large shallow lake (Balaton, Hungary) a dynamic approach to ecological memory, its possible role and mechanisms. J Ecol 80:217-30.

Pearl HW, Huisman J. 2008. Blooms like it hot. Science 320:57-8.

Pearl HW, Otten TG. 2013. Harmful cyanobacterial blooms: causes, consequences and controls. Microb Ecol 65:995-1010. doi:10.1007/s00248-012-0159-y.

Pelletier J-P, Orand A. 1978. Appareil de prélèvement d'un échantillon dans un fluide. Brevet d'invention 76:08579.

Personnic S, Domaizon I, Sime-Ngando T, Jacquet S. 2009. Seasonal variations of microbial abundances and virus-versus flagellate-induced mortality of picoplankton in three peri-alpine lakes. J Plankton Res 31:1161-77.

Pomati F, Matthews B, Jokela J, Schildknecht A, Ibelings BW. 2012. Effects of re-oligotrophication and climate warming on plankton richness and community stability in a deep mesotrophic lake. Oikos 121:1317-27.

Posch T, Koester O, Salcher M, Pernthaler J. 2012. Harmful filamentous cyanobacteria favoured by reduced water turnover with lake warming. Nat Clim Chang 2:809-13.

Reynolds CS. 1999. With or against the grain: responses of phytoplankton to pelagic variability. Mar Biol Assoc U K Occas Publ 6:15-43.

Reynolds CS. 2006. Ecology of phytoplankton. Cambridge: Cambridge University Press.

Rigosi A, Carey CC, Ibelings BW, Brookes JD. 2014. The interaction between climate warming and eutrophication to promote cyanobacteria is dependent on trophic state and varies among taxa. Limnol Oceanogr 59:99-114.

Salmaso N, Cerasino L. 2012. Long-term trends and fine year-toyear tuning of phytoplankton in large lakes are ruled by eutrophication and atmospheric modes of variability. Hydrobiologia 698:17-28.
Savichtcheva AO, Debroas D, Perga ME, Arnaud F, Villar C, Lyautey E, Kirkham A, Chardon C, Alric B, Domaizon I. 2014. Effects of nutrients and warming on Planktothrix dynamics and diversity: a palaeolimnological view based on sedimentary DNA and RNA. Freshw Biol 60:31-49. doi:10.1111/fwb. 12465.

Scheffer M, Straile D, Van Nes EH, Hosper H. 2001. Climatic warming causes regime shifts in lake food webs. Limnol Oceanogr 46:1780-3.

Shatwell T, Köhler J, Nicklisch A. 2008. Warming promotes cold-adapted phytoplankton in temperate lakes and opens a loophole for Oscillatoriales in spring. Glob Chang Biol 14:1-7.

Sivonen K, Jones G. 1999. Cyanobacterial toxins. In: Chorus I, Bartram J, Eds. Toxic cyanobacteria in water. London: E \& FN Spon. p 41-111.

Stich HB, Brinker A. 2010. Oligotrophication outweighs effects of global warming in a large, deep, stratified lake ecosystem. Glob Chang Biol 16:877-88.

Straile D, Kerimoglu O, Peeters F, Jochimsen MC, Kümmerlin R, Rinke K, Rothhaupt K-O. 2010. Effects of a half a millennium winter on a deep lake-a shape of things to come? Glob Chang Biol 16:2844-56.

Taranu ZE, Zurawell RW, Pick F, Gregory-Eaves I. 2012. Predicting cyanobacterial dynamics in the face of global change: the importance of scale and environmental context. Glob Chang Biol 18:3477-90.

Trolle D, Hamilton DP, Pilditch CA, Duggan IC, Jeppesen E. 2011. Predicting the effects of climate change on trophic status of three morphologically varying lakes: implications for lake restoration and management. Environ Model Softw 26:354-70.

Utermöhl H. 1958. Zur Vervollkommung der quantitativen Phytoplankton-methodik. Mitteilungen Internationale Vereinigung für theoretische und angewandte Limnologie 9:1-38.

Vinçon-Leite B. 2014. 2014 Fonctionnement des écosystèmes lacustres dans les bassins versants anthropisés-mesures et modèles. Janvier: Mémoire d'habilitation à diriger des recherches de l'Université Paris-Est.

Walsby A, Avery A, Schanz F. 1998. The critical pressures of gas vesicles in Planktothrix rubescens in relation to the depth of winter mixing in Lake Zurich, Switzerland. J Plankton Res 20:1357-75.

Weyhenmeyer GA. 2001. Warmer winters: are planktonic algal populations in Sweden's largest lakes affected? Ambio 30:565-71.

Wigley TML, Raper SCB. 2001. Interpretation of high projections for global-mean warming. Science 293:451-4.

Winder M, Schindler DE. 2004. Climatic effects on the phenology of lake processes. Glob Chang Biol 10:1844-56.

Winder M, Sommer U. 2012. Phytoplankton response to a changing climate. Hydrobiologia 698:5-16. 